\title{
The Obstacles of Implementation of Village Allocation Fund Program in the North Konawe Southeast Sulawesi
}

\author{
Hardi Warsono ${ }^{1} \&$ dan Ruksamin ${ }^{1}$ \\ ${ }^{1}$ Doctoral Program of Public Administration, Faculty of Social and Political Sciences, Diponegoro University, \\ Semarang, Indonesia \\ Correspondence: Hardi Warsono, Doctoral Program of Public Administration, Faculty of Social and Political \\ Sciences, Diponegoro University, Building of Postgraduate Diponegoro University; 5th Floor, Imam Bardjo, SH \\ Street No. 3-5 Semarang, Indonesia. Tel: 62-857-2697-2565 or 62-856-4113-0512. E-mail: \\ programdap@yahoo.com
}

Received: June 10, 2014 Accepted: August 5, $2014 \quad$ Online Published: August 29, 2014

doi:10.5539/jms.v4n3p175 URL: http://dx.doi.org/10.5539/jms.v4n3p175

\begin{abstract}
Provision of Village Allocation Fund is predicated on the realization of the right to hold the village of village autonomy. This is done so that the village can grow and evolve to follow the growth coming from the village itself based on diversity, participation, indigenous autonomy, democratization, and empowerment. Rural Institutions have increased due to the ability of an optimal are not adequately involved in the planning process using the Alokasi Dana Desa (ADD) village without there even through the planning process as the existing guidelines, were never involved in the implementation of ADD and also have never been involved in the evaluation of the implementation of the ADD, all plans activities and filing submitted to Badan Pemberdayaan Masyarakat Desa (BPMD). This phenomenon shows that community involvement is still an obstacle. The main barriers associated with the management of the village administration who have not gotten the right formula in community involvement, especially in aspiration. That is because of the following: 1) The low level of public education 2) Weak managerial ability of the village and other village institutions and 3) Failure mechanisms of socialization and increased capacity building by BPMD to the village.
\end{abstract}

Keywords: Dana Village, aspiration, empowerment

\section{Introduction}

Model of development which is involving the community also called as a model of participatory development. Implementation of participatory development is a logical consequence of the demands of reform and openness desired by the society, the government transit system from new government period (Government of Orde Baru) to the reform system, which is also supported by the principles of governance as stipulated in Law No. 32 year 2004 on Regional Government that implemented the importance mandates of regional autonomy, democratization, participation and decentralization of authority to govern and development at the local level.

Occurrences of Village Allocation Fund is a demand of the Law No. 32 Year 2004 on Regional Government and Government Regulation No. 72 Year 2005 about the village, both regulatory proficiency level in explaining that the village was given legal certainty to the financial equilibrium of the village and district/city. And administration of the Village Allocation Fund is predicated on the realization of the village's right to hold village autonomy. It is done so that the village can grow and flourish following the growth coming from the village itself based on diversity, participation, genuine autonomy, democratization, and empowerment.

The access of public services in the city more develop than in the village so that public service more gaps from time to time. This kind of development strategy will not be able to overcome structural poverty. The number of rural poverty will always be higher and will increase the continuity of urbanization. In line with these problems, in 2005 the government issued a policy of the Village Allocation Fund (ADD), which is characterized by the issuance of Government Regulation No. 72 of 2005, whose purpose is more directed in the village development scale.

The implementation of the Village Allocation Funds (ADD) is set by the government in Government Regulation No. 72 Year 2005 about village. In Article 68 paragraph 1 letter c, explained that part of the balance of central 
and local funds received by the district/city for the village at least $10 \%$ of the distribution for each village proportional which is the Village Allocation Fund. Regulations of Allocation Village Fund followed up by the Minister of Home Affairs Circular No. 140/640/SJ of 2005 on the Implementation of Village Allocation Funds directed to the Governor and Regent/Mayor throughout Indonesia to immediately realize the Village Allocation Funds, especially to the District/Municipal that is never implementing Village Allocation Fund before. In the Circular, the Minister of Home Affairs premises clearly states that the acceleration of the Village Allocation Fund to support performance improvement of village government.

Village Allocation Fund or commonly called ADD was fund giving to village from financial balance of Regional and central government received by the District/Municipal (Article 1, Section 11, PP No.72/2005). The purpose of Village Allocation Fund is to finance the village government program in carrying out the activities of government and society empowerment. While the purpose of the Village Allocation Fund itself, include of:

1) To improve the administration of villages government in implementing government services, and social development in accordance with their authority.

2) To enhance the ability of an association of villages in the planning, implementation and control of development participatory in accordance to the potential of village.

3) To increase the income distribution, employment and business opportunities for rural communities.

4) To encourage increased community self-help mutual aid.

5) To follow up on Government Regulation No. 72 Year 2005 concerning Rural and SE of Minister No.140/640/SJ about Allocation Guidelines in the North Konawe, North Konawe Government and Parliament have established a Village Allocation Fund Policy and Regulation of Regents of the Technical Guidelines or Village Allocation Fund Guidelines. An Village Allocation Fund Policy in North Konawe implemented starting in 2011, it is an implementation of village autonomy Policy in North Konawe.

6) North Konawe formed based on The Act. No 13 Year 2007, that is one widened from the district of Konawe as district host. The purpose of the division is to spur the development and progress of Southeast Sulawesi province in general and North Konawe in particular, as well as the growing aspirations of the people, in order to improve the governance, implementation of development, and public services in order to accelerate the realization of public welfare.

7) Establishment of North Konawe was expected to encourage increased service in the field of governance, development, and social, as well as provide the ability to use the potential of the area. As one of new districts in readiness, srtucture and infrastructure are still needed in efforts to accelerate development in the North Konawe. (Act No. 13 Year 2007).

8) Government of North Konawe in Southeast Sulawesi province, is one of the few districts that have plan and implement ADD Policies. Implementation of ADD in North Konawe is based on the reality that as a pillar of regional autonomy, the village more requires a balanced funding to run a more concrete role in regional development. Government of North Konawe hopes that the Village Allocation Fund to rural, participatory planning will be more sustainable, because of people can be directly involved in the making of the planning documents in his village and joined it happen.

9) In North Konawe, the Village Allocation Fund Policy started in 2011. The purpose is to finance the village administration program in carrying out governance activities and vilage development scale as a form of implementation of village autonomy policy. Activities which are financed from the Village Allocation Fund should be concentrated on the activities that have been listed on the results of musrenbangdes covering economic, social, cultural, physical and general infrastructure. To see an increase in the budget Village Allocation Fund in North Konawe can be seen from Table 1.

Table 1. The development of the Village Allocation Fund of North Konawe

\begin{tabular}{llll}
\hline No & Year & Sum-scale APBD $($ Rp) & Scale of ADD (Rp) \\
\hline 1. & 2011 & 476.212 .362 .566 & $3.325 .000 .000,-$ \\
2. & 2012 & 518.989 .047 .025 & $3.990 .000 .000,-$ \\
3. & 2013 & 581.236 .387 .671 & $26.600 .000 .000,-$ \\
\hline
\end{tabular}

Source: PMD Institution, North Konawe District, 2013. 
ADD spike very fantastic magnitude of Rp 3.99.000.000,- to be Rp 26.600.000.000,- requires careful of management. How is the condition of the institutional society fund of management to be focus of this study? Based on this conditions, this study want to answer: (i) how model absorption of aspirations of ADD Programs in North Konawe?, (ii) what the main obstacles to the implementation particularly in absorption of aspirations of the society in the ADD program in North Konawe?

Pamuji, Hariman (2011), with his study entitled "The Impact of Village Allocation Fund (ADD) Against Economic Development In Pinang City, South Labuhanbatu District"“"Dampak Alokasi Dana Desa (ADD) Terhadap Pengembangan Ekonomi Di Kecamatan Kota Pinang Kabupaten Labuhanbatu Selatan”, concluded that the policy of the Village Allocation Fund Program (ADD ) in Pinang City, District of South Labuhanbatu went pretty smoothly. It can be seen from the preparation phase of Register Proposed Plan preparation activities (DURK), the implementation of each activity, the evaluation activity up to liability phase. Society income of Pinang City increased after the ADD program there.

Sari, Dini Gemala (2010) with her study "Relationship of Village Allocation Fund and Village Development in Stabat, Langkat District" focuses on the relationship Village Fund allocation with Village Development in Stabat, Langkat district, North Sumatra Province concluded that there is a significant relationship between the village allocation fund with village development in Stabat, Langkat district and there is positive public perception about the benefits of the use of Village Allocation Fund with village development in Stabat, Langkat.

Simanjuntak, Wira Gusni (2010), his study "Analysis of Village Allocation Fund Budget Serdang Bedagai against Rural Development In Sub-district Sei Rampah" / "Analisis Alokasi Dana Desa APBD Serdang Bedagai Terhadap Pengembangan Desa Di Kecamatan Sei Rampah". The purpose of this study was to analyze whether is there a difference of average income of households after the implementation of the Village Allocation Fund in Regional District of Sei Rampah and analyze the benefits of Village Allocation Fund toward the rural Development from leaders and community responses in District of Sei Rampah Serdang Bedagai regency of North Sumatra Province. The results obtained are: There are differences in people's income after the implementation of the Allocation Village Fund in Sei Rampah District.

From other research seems that ADD was considered the benefits for rural communities.

\section{Method}

The background of raise of policy analysis activities triggered by a number of policies that are not satisfactory in the sense cannot solve the problem, in fact it raises new problems. A coverage policy analysis process generally includes: problem identification, alternatives identification, selection of alternatives and the best alternative proposal. The process of policy analysis is sometimes performed before taking determine the best alternative to be implemented or after the best alternative was implemented.

\subsection{Problem Identification}

Problem identification is a process to identify and determine the issues that need to be taken seriously. The information about public policy issues can be obtained by various indicators of development, such as minimum service standards (SPM) in the implementation of obligatory functions, evaluation of medium-term development plan (RPJM), survey of reports, journals or interviews directly to the public.

\subsection{Alternative Identification}

If the goal had been approved, the question in the next stage is what is model or theory that it is able to identify the causes factor and based on the analysis is development to policy alternatives. At this stage an important question that needs to be answered is, "Is there a logical relationship between each alternative with the goal?"

To be able to identify appropriate alternative an analyst must have a sufficient theory on the problem to be solved. With the provision, the analyst will break down into the factors that cause the problems and translate into alternative solutions. Theoretical aspects must be stronger by the practical aspects so that policy alternatives that can be operationalized.

\subsection{Selection Alternative}

To be able to select the alternative selection and choose the policy alternatives that will be presented to policy makers, there should be a criteria or rational standards. Based on criteria or rational standards, an analyst can recommend the best alternative. Bardach in Patton \& Sawicki (1986) suggested several alternative selection criteria include of: technical feasibility; economic and financial possibility; political viability; administrtatif operability. While Dunn (1994) also suggests four (4) "multi- rational" criteria as follows: technical rationality; economic rationality; legal rationality; social rationality. 
This multi-rationality approach selects or recommends the best policy alternatives using ranking systems. In addition to the ranking system can be used index system when the weight of all is same. Nevertheless, the selection criteria are actually highly dependent on the destination. Several different purposes, among others: the planting of new cultural values, economic benefits, political interests. Therefore, it is needed a different weighting according to the agreement.

In general, the determination of the criteria using two principles, namely: (1) rationality (2) democracy. Rationality principle is applied to get the best alternative according to the rules of science, such as the analysis of costs and benefits. It must be calculated some costs to be incurred in the implementation of each alternative and how the benefits that can be obtained when one alternative is implemented. Calculations and comparisons can be made based on agreed criteria, but because in most cases there is a lack of information or the ability to analysts, it is necessary that the second principles, that is democracy. Democracy principle is the principle of alternative selection which is engaging of stakeholders. Alternative only acceptable approved by the stakeholders or interested parties through a forum for dialogue, discussion and so on.

\subsection{Endorsement and Policy Formulation}

The policy validation process is usually called decision making. If the proposed policy has been adopted and approved by the authorities, the proposed policy has turned into a legitimate policy (legitimate). The valid policy is further binding on all parties associated or parties to whom the policy target. In democratic countries, the basic principle in the policy endorsement is "majority coalition building" or "majority vote", it means that if the majority of the parties involved in the approval process has been agreed, then the validation can be done. In Indonesia, the cornerstone of policy formulation and validation is done by the principle of "deliberation (musyawarah) and consensus (mufakat)". If there is a stalemate in musyawarah/deliberation and mufakat/consensus then performed voting or taking the bigest voice.

James E. Anderson in Islamy (1986) argued that the policy approval process usually starts from the "persuasion" and "bargaining". These activities include efforts to convince others of the truth or value of proposals and ideas so that they (the relevant parties' bargain) accept as true. People seeking support others, it is need to make sure that his opinion is correct, and useful for the targeted communities as needed, so that the other party then support and justify their opinions.

This type of this research is descriptive qualitative because it is the disclosure of descriptive phenomena without considering the quantity emergence of the phenomenon, but the depth of information on each phenomenon. Descriptions of research methods as follows: (1) the type of research; this research is descriptive qualitative because this type of disclosure is descriptive phenomena without considering the quantity of the emergence of the phenomenon, but the depth of information on each phenomenon. (2) subjects and site/focus of study: This study focuses on search the stakeholders involved, the procedure of absorption of the public aspiration procedures and the obstacle in preparation for the implementation of Village Allocation Fund in North Konawe. (3) data sources; primary data obtained from key informants, the related department, District, Village and other selected implementor for ADD. (4) the techniques of data collection; collection of data is done with the focus group discussion (FGD) involving actors that inclusive education as determined through by searching that started from the district office. (5) the analysis and interpretation of data; data are presented with a narrative technique. (6) the quality of research (goodness criteria); this research is expected to gain an advantage in terms: the theme has not been widely discussed in Public Administration Sciences, Fisip Undip, using techniques that provide the flexibility of its implementation so that the information can be rich, and (7) weakness/study limitations: because of the specificity of the location, which is relatively far remote areas, lack of data cannot be met maximum.

\section{Results}

\subsection{Model of Absorption of Society Aspiration of ADD Programs in North Konawe}

a. Model 1: Absorption and Activity Proposal Process of ADD Program accordance with applicable regulations.

Not many villages that carry out the process of aspiration absorption and proposal activities of ADD program in accordance with applicable regulation. One of them is Bandaeha village. As told by the village chief and Chairman of their BPD is as follows: Mahmud (Chief Bandaeha Village of Molawe, North Konawe).

"Yah... Well, if we pack in the village during this time we've run in accordance with the existing technical guidelines, where this ADD activity implemented. We starting from Bimtek activities (Technical Guidance) held by BPMD and village government of North Konawe, after the activity Bimtek, we invite all officials and community leaders of Bandaeha village to conduct meetings to discuss the program based on ideas from the 
community as well as representatives from other community groups, from these meetings are carried out and then we put together a program of activities in budget revenue village shopping village ( APBD ), after all has been completed, we transfer to the Local Government in this regard to BPMD for verification and get new approvals to be under cashed by BPKAD to be cash the budget to our village account, Sir. After cash of budget first time phase, then we held coincidence events by community and it is approved by BPD (Institution of Village Consultative) it is the drainage works, while holding implementation and will be evaluated by the community itself too ...."

"It is true, Sir, in this case in BPMD (Agency for Community Empowerment and Rural) district of North Konawe has prepared a draft and we were asked also if you want to input any proposal, and then received his money, lived alone execute the job... but I think unless we in this village had no one can work, then we give to people in BPMD, but we can own, Sir... as long as we work in accordance with existing guidelines and we would definitely be patient and done well proven ..."

Meanwhile a similar case presented by Drs. Hikmar (BPD Chairman Badaeha Village Molawe, North Konawe) :

"Well, Sir ... If it's in our village had been running this program with either the ADD policy well, because our knowledge, Sir.. there is of existing rules, so what else we want held that does not comply with the rules or the technical guide there, because now Sir, people have known and understand from this program..... but the most important thing is, I as Chairman of BPD Village Bandaeha already reminded Head Office and his officials.. so do not try to carry out the provisions of this program outside of the rules. If we know the legal ramifications, the Village should be responsible... what is the point we have officers that almost all bachelor have the ability, and this is where we prove that we also have the resources and are able to implement if given the responsibility. So, I personally and institutionally salute to Head Office.

b. Model 2: The implementation of the ADD program, in accordance with the applicable plan, but its manufacture of APBD submitted to BPMD of North Konawe District.

Many of the villages through village consultation aspiration, but the making of a proposal documentary submitted to BPMD. One of them is Puulemo village. The following narrative Puulemo's village head.

Bambang (Village Head Puulemo, Kec.Lembo) :

"If we are here, especially in the village of Puulemo, Lembo ... Alhamdulillah already understand the policy of Village Allocation Fund (ADD) from the local government of Konawe, especially before we have got Bimtek in the district .... so its implementation in accordance with what is expected ... while the mechanism in accordance with the results of the training was that, sir .... just frankly, sometimes we also are confused about where to start? This is because we are here, in the village whose name Pulemo very limited human resources, while meeting if all this talk and it arrived already implementing what the decision is no one willing to carry out .... so the results of the deliberations that we do that we have not been able to make in accordance with what has been taught time technical guidance .... to anticipate it, we transfer it to the BPMD and there we ask for more help in the drafting of the budget that will be proposed later. But at the core of all of our processes are carried out only to make it in the concept, frankly we are very limited, but the results are not out of the existing rules."

Meanwhile, one resident Hj. Marni (Puulemo Village Community Leader) said:

"I was just a small community, we don't know the problem and the program? I've only seen about a meeting of district program whose name is ADD, only that, we also look after this meeting and it was a fight, then silence, suddenly existing activities ..... yes I thank goodness we have become a society has never been directly involved in activities like this before, suddenly we are also sorry already participated in the planning and I've even been offered assistance in the form of capital increase my stall that I manage ..."

c. Model 3: Implementation of the ADD program, ranging from the proposed plan, until the making of the budget submitted to BPMD of North Konawe District.

The majority of villages in North Konawe falls into this category. Here's one of the village head. Weli (Village Head Wawolesea, Kec. Lasolo, Kab. North Konawe):

"yes, in our village, Sir... the implementation of ADD has been executed, if the issue of why we are not meeting and even why we leave it to BPMD? I say this honestly, first, my community here is not the same as other people in the village, was convened here not necessarily because they want to attend them all busy, the second is the average of what we say that is accepted by those who come, so I'm thinking of the old will make the results as well, we better get on with it, and here are three of my officers pity, on average very limited, let alone want to make this, just think sometimes they are lazy, because I want them know, how important they've been told, they 
were not all sorts again ..... based on that, then we bother making long, I better find a quick way, happened to be there that can help me, the proof they all receive also what we are programmed and proved to all that we want to happen as well as provisions that have been confirmed by the government .... in essence, as long as we want and not break the rules, all can be arranged."

Meanwhile Musnah (Apparatus Wawolesea Village, Kec. Lasolo, Kab. North Konawe) said:

"I'm, as village officials Wawolesea during this almost never know if there are programs that are running ADD, just as I know it is a program of the provincial government, namely Block Grand .... so, Sir, what the village head mother, I did not agree, as long as I have not been invited as a society all of a sudden there was a program implemented .... if the reason human resources here is limited or less it is also not true because many are here already know that the computer would simply typing the proposed program and budget ... so maybe my expectations as a society that this should be a future improvement of the system and the implementation of policies ADD models that are running by the regional government of North Konawe .... So I know they arrange themselves so that they are free, no one bothers ....."

\section{Discussion}

\subsection{The Mean Obstacles}

The requirements to be able to implement the state policy perfectly according to the theory of Brian W. Hogwood and Lewis cited A. Gun Solichin Abdul Wahab, namely:

a. External conditions faced by the implementing agency or agencies will be uninterrupted or serious constraints. The constraints possible physical nature, politics and so on;

b. For the implementation of the programs available time and resources are sufficient;

c. The combination of the necessary resources actually available;

d. Wisdom will be implemented based on the reliable causal relationship;

e. Causality is direct and only a few connecting chains;

f. Relationship of interdependence is small;

g. Deep understanding and agreement on goals;

h. Itemized tasks and placed in the proper order;

i. Communication and coordination are perfect;

j. Parties who have authority and power to sue to get perfect compliance (Solichin Abdul Wahab, 1997:71-7).

Rural Institutions have not experienced an increase in ability is not optimal because too much involved in the planning process is the use of ADD even without going through the village planning process as existing guidelines, were never involved in the implementation of ADD and also have never been involved in the evaluation of the implementation of the ADD, all plan activities and filing submitted to BPMD.

This phenomenon shows that the involvement of the community is still experiencing major obstacles. The mean obstacles associated with the management of the village administration who have not gotten the right formula in community involvement, especially in aspiration. That is because of the following: The low level of public education; The weakness of managerial ability of the village and other village institutions; The failure socialisation mechanism and increasing capacity building by BPMD to the village.

\subsection{Absorption Aspirations on the Implementation of the Program of ADD in North Konawe for the Future}

Communication is an important factor in aspiration. It often happens that a failure of public policy to achieve its objectives due to the lack of understanding of the execution of the commands execution, both the context and the content of the policy itself. For that a policy should be communicated so that implementers can understand and comprehend what should do. In this study, communication refers to the notion put forward by Robbins (2002:146), namely "penyampaian dan pemahaman dalam sebuah arti"/ "the delivery and understanding in a sense." In the context of public policy implementation, Edwards (Winarno, 2012:178) mentions three important things in the communication process policies, namely "transmission, consistency and clarity." That policy has been decided to be forwarded to the executor (implementor) to follow. Communication should be accurate, clear and consistent in order to be understood carefully by implementers, not interpretations and even confusing.

There are three indicators that can be used to measure the success of the communication variables. Edward III in Agustino (2006:157-158) argues that the three variables, namely: 
1) Transmission. Distribution of good communication will produce a good implementation anyway. Often there are problems in the distribution of communications that is the wrong sense (miscommunication) that due to the many levels of bureaucracy that must be passed in the communication process, so that what is expected distortion in the middle of the road.

2) Clarity. Communications received by the policy implementers (street-level-bureaucrats) should be clear and not confusing or ambiguous/ambivalent.

3) Consistency. Commands given in the commission of a communication must be consistent and clear to set or run. If the command is given frequent changes, it can cause confusion for implementers on the field.

From the research in relation of communnication with the implementation of ADD, there are several factors driving and inhibiting. Some aspects of the driving force are: Socialization conducted by the District Team; Achievement information from policy makers to policy implementers running smoothly; There is consistency in the achievement of the message/command policy means there are no conflicting orders.

An obstacle aspect in the communication is public education about ADD policies have not been up even impressed not on target, so that people's understanding of the purpose of ADD is very less, this is resulting in difficulty to invite the community to participate in the implementation of ADD as well as in terms of supervision activities. On the other hand the problems that arise are less precisely the achievement of program objectives. This means that programs originally planned and budgeted to be funded is often replaced by another program that turns out to have a greater interest for priority. This condition describes the budgeting planning mechanisms that are less mature so that an error occurred in the prioritization of funding at an early stage. Early indications are the basis for setting priorities inaccuracy lies in the lack of socialization of policies ADD so less touches on the community which is directly implementing programs or activities funded by ADD. Lack of community participation in giving suggestions about what programs are urged to programmed ADD activities.

On that basis, in implementing the policy of ADD in the villages as policy implementers must consider a variety of aspects. The flow of information and communication need to be considered so there is no understanding of the difference between the contents of the policy provided by the local government with executive officers in the perception of village communities even as a target group. It is also necessary resource support stakeholders related to the implementation of Village Allocation Funds policy (ADD) in North Konawe.

Aspects of communication are very influential in policy acceptance by the target group, so that will affect the quality of communication in achieving the effectiveness of policy implementation ADD. Thus, the content of the policy deployment process through good communication will affect the policy of implementation ADD. Communication media used to disseminate content to the target group policy or implementation will be needed in the village.

\section{Conclusions}

1) The Role of Local Government to realize the strategic autonomy of the village, both genuine autonomy from the origin of the village itself and gained autonomy as a consequence of the principle of decentralization. Law No. 32 Year 2004, in particular Article 12 paragraph (1) emphasizes that: affairs are left to the local government must be accompanied by funding source, diversion facilities and infrastructure, and personnel in accordance with the decentralized affair. Village Autonomy is an autonomous native, round and whole and not a gift from government. Instead the government is obliged to respect indigenous autonomy owned by the village.

2) As the unity of the legal community who have legal structures, both public and private law, has the wealth, property and may be prosecuted and courts demanding upfront. To improve the ability of the village to explore its potential, North Konawe government is formulating a policy that is appropriate for the community empowerment improvement of local resources to spur rural development by empowering potential scale locally owned village. The Village Allocation Fund Policy (ADD) is one concrete manifestation of autonomy in the implementation of its objectives is the strengthening of rural communities in building and strengthening rural village government in running the village administration system that is followed by changes in the socio-economic structure of society, supporting the development potential of the community by increasing the productivity and efficiency.

3) Implementation of village autonomy is running well in North Konawe Province of Southeast Sulawesi as well as in other districts in Indonesia, still encounter problems very fundamental and impact on the effectiveness of the implementation of the autonomy of the village itself, in terms of legislation this village autonomy still lacking this can be seen from the various problems encountered by each implementing country governments, both the quality and quantity of resources required is very limited. As a logical consequence of the local 
government should be able to create a policy that can address the problems that exist in society, administration building programs directly to the village is one such solution because the program can involve the community directly in the development process with usually called as society participation.

4) At the conclusion which can be drawn by the researchers on the autonomy of the village who was running with the enormous complexity of the problem that led to the weakness of the rule or law that can fully accommodate the interests of the village, this is more of a discourse, not the goal itself village autonomy namely the creation of village participation in running the government as a spearhead in the area of self-autonomy by increasing the scale of development in a fair and prosperous village.

\section{Suggestions}

1) Technical manual implementation (technical guidelines) ADD needs to review the draft regulations and the absence of the filing of the area that will be in charge of local regulations (PERDA) of Policy of The Village Allocation Fund in Noth Konawe, so there is a regulatory standard and a reference in planning, ADD implementation activities in the village.

2) The village allocation funds (ADD) are needed for improved governance, and social development, the achievement of this goal has been accomplished optimally. Achievement of this goal is optimal because there are a number of villages in the district of North Konawe is categorized rural poor village so desperately need the help of the village fund allocation in order to improve governance, and social development. While the Village Fund Allocation in another region or another country that is considered able to contribute greatly for, then ADD strongly support an increased governance, and social development.

3) Increasing the ability of an association of villages in the planning, implementation and control of development is indispensable. Achieving this goal is not running optimally, because the only social institution involved in the planning and implementation of activities while in control were excluded. The need to increase the participation of non-governmental mutual aid society.

4) The need for submission of model of implementation of Village Allocations Fund policy (ADD) more comprehensive it is influenced by aspects of existing policies that have implications for the implementation of village autonomy is running.

\section{Acknowledgements}

I said thanks to the Rector of Diponegoro University, Dean of the Faculty of Social and Political Sciences and Regents North Konawe who have helped and supported the writing of this article.

\section{References}

Arikunto, S. (2006). Prosedur Penelitian. edisi kedua, Penerbit Rineka Cipta Jakarta.

Ary, D., Jacobs, L. C., \& Rezavieh, A. (1976). Pengantar Penelitian Pendidikan. Terjemahan oleh Arief Furchan, 1982, Usaha Nasional. Surabaya.

Bogdan, R. C., \& Biklen, S. K. (1982). Qualitative Research for Education: An Introduction to Theory and Methode. Boston: Allyn and Bacon, Inc.

BPS Cataloque. (2011). Konawe Utara Dalam Angka 2011. PBS Kabupaten Konawe Utara.

Brannen, J. (1993). Mixing Methods; Qualitative and Quantitative Research. Aldershot, England: Avebury Ashgate Pub. Ltd.

Bungin, B. (2003). Analisis Data Penelitian Kualitatif. Raja grafindo Persada, Jakarta.

Cohen, Louis, \& MManion, Lawrence. 1994, Research Methosds in Education. New York : Routledge.

Cresswell, J. (1998). Research Design: Qualitative \& Quantitative Approaches. Thoussand Oaks, CA: Sage Publications.

Dunn, W. N. (2003). Analisis Kebijakan Publik. PT Hanindita Graya Widya, Yogyakarta. UGM, Yogyakarta.

Dyer, J. C. IV, \& McHugh, A. J. (1975). The Timeliness of The Australian Annual Report. Journal of Accounting Research.

Edward III, \& George, C. (1980). Implementation Public Policy. Washington: Congressional Quarterly Press.

Effendi, S. (2000). Kuliah Umum Perdana MAP UNDIP. Semarang.

Flippo, B. E. (1999). Personal Management. Singapore: Mac Graw Hill Inc.

Gordon, J. R. (1990). A Diagnostic Approach to Organizational Behavior. Boston: Allyn and Bacon. 
Handoko, H. (1980). Managemen, Edisi II, (terjemahan), BPFE, Yogyakarta.

HAW, W. (2003). Otonomi Desa. PT Raj Grafindo Persada, Jakarta.

Islamy, M. I. (2001). Prinsip-prinsip Kebijakan Negara. Bumi Aksara, Jakarta.

Koontz, H., \& O'Donnell, C. (1981). Prinsip - Prinsip Management. Bhratara Jakarta.

Mazmanian, D. H., \& Sabatier, P. A. (eds.). (1983). Implementation and Public Policy. New York: Harper Collins.

Miles, M., \& Humberman, M. (1994). Quatitative Data Analysis. Sage Publication.

Moekijat. (1990). Analisa Kebijakan Publik. Mandar Maju, Jakarta.

Moleong, L. J. (2000). Metodologi Penelitian Kualitatif. Remaja Rosdakarya, Bandung.

Mubyarto. (2000). Membangun Sistem Ekonomi. BPFE Yogyakarta.

Muhammad, A. (2001). Komunikasi Organisasi. Bumi Aksara, Jakarta.

Nasir, M. (1993). Metode Penelitian. Ghalia Indonesia, Bogor.

Patton, M. Q. (1990). Quantitative Evaluation and Research Methods (2nd ed.). California: Sage Publications.

Peraturan Pemerintah Nomor 72 tahun 2005 tentang Desa.

Poerwandari, E. K. (1998). Metode Penelitian Sosial. Universitas Terbuka, Jakarta.

Quade, E. S. (1984). Analisis for Public Decision. Nort Holland, New York.

Republik Indonesia, Peraturan Presiden Republik Indonesia Nomor 7 tahun 2005 Tentang Rencana Pembangunan Jangka Menengah Nasional Tahun 2004-2009 (RPJMN), Sinar Grafika Jakarta.

Robbin, S. P. (2001). Perilaku Organisasi. PT Prenhalindo, Jakarta.

Simamora, H. (2006). Manajemen Sumber Daya Manusia. Cetakan ketiga belas, Bumi Aksara, Jakarta.

Singaribun, M., \& Effendi, S. (2000). Metode Penelitian Survei. Jakarta LP3ES.

Solly, L. M. (1988). Kebijakan Publik Politik dan Hukum. Mandar Maju, Jakarta.

Sprandley, J. P. (1980). Participant Observation. Holt Rinehart and Winston.

Subarsono, A. G. (2005). Analisis Kebijakan Publik. Pustaka Pelajar, Yogyakarta.

Sugiyono. (2002). Statistik Penelitian. Penerbit Alfabeta Bandung.

Tjokrowinoto, M. (2001). Birokrasi dalam Polemik. Pusat Studi Kewilayahan Universitas Muhammadiyah Malang.

Undang-Undang Nomor 32 tahun 2004 tentang Pemerintahan Daerah.

Undang-Undang Nomor 33 tahun 2004 tentang Perimbangan Keuangan Daerah

Undang-Undang Nomor 5 tahun 1974 tentang Pemerintahan Daerah.

Undang-Undang Nomor 5 tahun 1979 tentang Pemerintahan Desa.

Van Meter, D. S., \& Van Horn, C. E. (1975). The Policy Implementation Process: A Concentual Framework in: Administration and Society, 6(4), 445-485. http://dx.doi.org/10.1177/009539977500600404

Wahab, S. A. (2001). Analisa Kebijakan: Dari Formulasi ke Implementasi Kebijaksanaan Negara. Bumi Aksara, Jakarta.

Wibawa, S. (1994a). Implementasi Kebijakan Publik. Penerbit Balai Pustaka, Jakarta.

Wibawa, S. (1994b). Kebijakan Publik, Proses dan Analisis. Intermedia, Jakarta.

Winarno, B. (1998). Teori dan proses Kebijakan Publik. Media Pressindo Yogyakarta.

\section{Copyrights}

Copyright for this article is retained by the author(s), with first publication rights granted to the journal.

This is an open-access article distributed under the terms and conditions of the Creative Commons Attribution license (http://creativecommons.org/licenses/by/3.0/). 